\title{
The African American Minister as a Source of Help for Serious Personal Crises: Bridge or Barrier to Mental Health Care?
}

\author{
Harold W. Neighbors, $\mathrm{PhD}$ \\ Marc A. Musick, PhD \\ David R. Williams, $\mathrm{PhD}$
}

\begin{abstract}
Using data from the National Survey of Black Americans, this article explores the role of African American ministers in the help seeking of African Americans for serious emotional problems. The authors explore which demographic characteristics and psychosocial factors are related to contacting Black clergy for help, whether certain types of personal problems increase the likelihood of clergy contact, and whether those who go to ministers are also likely to seek help from other professional help sources. Results indicate that women are more likely than men to seek help from ministers. People with economic problems are less likely to contact clergy, while those with death or bereavement problems are more likely to seek help from the clergy. Regardless of the type or severity of the problem, those who contact clergy first are less likely to seek help from other professionals. It is recommended that African American clergy and mental health professionals engage in a mutual exchange of information to increase access to professional care among African Americans with serious personal problems.
\end{abstract}

National epidemiologic estimates show that while variations exist for some disorders, the prevalence of serious mental illness in African Americans is roughly equivalent to that of Whites. ${ }^{1,2}$ With the exceptions of schizophrenia and phobias, the Epidemiologic Catchment Area (ECA) Program found roughly comparable rates of mental disorders for Blacks and Whites. ${ }^{3}$ For example, age-adjusted analyses by sex showed no Black-White differences in the prevalence (lifetime and 6-month) of depression. ${ }^{4}$ Findings from the more recent National Comorbidity Survey (NCS) also show no significant Black-White differences in the 12-month prevalence of serious mental illness." The NCS does reveal,

*Results from the National Comorbidity Study (NCS) show that African American rates for some disorders were below those of Whites, particularly depression and substance abuse disorders. ${ }^{2,6}$ The exception was for phobias, where blacks had higher rates of agoraphobia. ${ }^{7}$ The NCS also revealed that Black women had higher current rates of agoraphobia and simple phobia than White women. White males had rates of simple and social phobia that were higher than those of Black males. ${ }^{8}$

Harold W. Neighbors is at the School of Public Health, the University of Michigan, Ann Arbor. Marc A. Musick and David R. Williams are at the Institute for Social Research, the University of Michigan, Ann Arbor.

Address reprint requests to Harold W. Neighbors, University of Michigan, School of Public Health, 1420 Washington Heights, Ann Arbor, MI 48109-2029; phone: (734) 936-9868; fax: (734) 763-7379; e-mail: woodyn@umich.edu

This research was supported in part by grants from the National Institute of Mental Health, the National Institute on Aging, and the Blue Cross Blue Shield Foundation of Michigan. The authors would like to thank Ms. Pat Bergeron for help in preparing the manuscript and the anonymous reviewers for comments. 
however, that African Americans with a serious mental illness are significantly less likely than Whites to seek treatment for mental problems. ${ }^{5}$ Data from the National Survey of Black Americans (NSBA) show that when need for treatment is defined by the presence of serious psychopathology, African Americans underuse mental health services. ${ }^{9}$ The NSBA also shows that African Americans in distress rely quite heavily on a variety of alternative help resources to compensate for their lack of access to specialty mental health care. ${ }^{10}$ Clergy, in particular, play a crucial role in meeting the mental health needs of African Americans. ${ }^{11-13}$

The African American minister occupies a truly unique place in the conceptual scheme of help sources. More than any other help resource, it has been argued that Black pastors are uniquely positioned to play two critical roles. The first is that of a primary mental health treatment source. The second role is that of a gatekeeper and referral source to specialty mental health care. Although there is a fair amount of research published on the socially supportive role of Black churches, ${ }^{14-16}$ surprisingly little has been written about the precise functions of Black minsters in counseling African Americans with mental health problems. Much of the literature on the mental health role of Black ministers remains more speculation and conjecture than empirical documentation. ${ }^{17-20}$ Furthermore, due to the relative lack of research, many of the interesting issues raised in investigations of White clergy have yet to be addressed with African Americans. ${ }^{19}$

As a result of the paucity of research on the mental health role of Black ministers, it remains an open question as to whether African American pastors are indeed providing a bridge to specialty mental health care. ${ }^{21}$ Thus, it is the purpose of this article to fill this gap by addressing important questions concerning the actual role African American ministers play when Blacks seek help for serious emotional problems. Four basic research questions are addressed in this article. First, we ask what demographic characteristics and psychosocial factors are related to contacting Black clergy for help. Second, we explore whether certain types of personal problems increase the likelihood of clergy contact. Third, this article addresses the critical question of whether those who do make contact with ministers are also likely to seek help from some other professional help source. We are particularly interested in describing patterns of multiple professional help use among those who contact ministers first in comparison to those whose initial contact is some other professional help source. Finally, this article documents the specific types of help offered by ministers and whether help seekers are satisfied with the help offered by Black clergy.

The analysis reported here takes advantage of previously unexplored data from the landmark study, the NSBA, ${ }^{22}$ to increase our understanding of the mental health service delivery role played by African American pastors. The NSBA remains a tremendous resource of untapped information on a variety of aspects of African American life. The NSBA was designed to document the extent to which Blacks in need of mental health care were obtaining it. More important, this study was designed to pinpoint the precise location of help sources for African Americans. Previous analyses of the NSBA, while answering many questions about Black help seeking, have raised a number of new questions, particularly with respect to how African Americans use specific professional help sources. Prior research on help seeking from the NSBA has focused much more on the decision to seek help in general than on a particular help resource. ${ }^{12}$ More important, there has never been an analysis of the NSBA data on the therapeutic functions and specific actions taken by Black ministers on behalf of help seekers. 


\section{The Mental Health Role of Black Ministers}

There are many reasons for studying the role of African American ministers as sources of mental health treatment. African Americans are a highly religious people. ${ }^{23}$ Data from the NSBA show that $68 \%$ of adult Blacks belong to a church and that $92 \%$ of members attend church. ${ }^{24}$ Given such high levels of church attendance, African American pastors naturally become an extremely accessible source of help by virtue of the fact that they are located within an organization that is clearly viewed by Blacks as a source of comfort and support. ${ }^{15,16}$ This overcomes one of the most difficult barriers African Americans face when considering specialty mental health care-the stigma attached to the possibility of being labeled "crazy" or mentally ill. Despite attempts to make mental health services more culturally relevant, many African Americans still view such services as foreign, even hostile, places. ${ }^{25}$ Thus, it makes sense that ministers, as respected community leaders, are one of the first people contacted by Blacks in psychological distress. As a result, it is imperative that we establish a clear and accurate description of the mental health treatment role played by African American clergy.

Recent data from the ECA show that U.S. clergy do not differ from mental health practitioners in terms of the type or severity of psychiatric disorders they see. ${ }^{21}$ Unfortunately, these analyses do not focus on African American clergy, evidence that the mental health role of Black ministers remains a neglected area of research. ${ }^{13}$ Thus, while no one would dispute the tremendously important role that Black ministers play in meeting the mental health needs of African Americans, important questions remain regarding the specific functions of Black ministers when they are contacted by someone in the midst of a serious emotional crisis. We know surprisingly little, for example, about the specific types of help offered by Black clergy during counseling sessions. To what extent are Black ministers able to recognize symptoms of depression or suicide risk? No one, to our knowledge, has been able to document how Black pastors operate with respect to referrals and whether these factors vary as a function of the type of problem or diagnostic category. Are Black ministers prone to refer church members to a mental health professional, or are they more likely to counsel the individual themselves? Because very little has been written about the outcomes of help-seeking encounters with ministers, we do not know the extent to which Blacks using the services of ministers are satisfied with the help they receive.

The literature contains some useful articles suggestive of the contributions that Black pastors make to community mental health. Levin ${ }^{18}$ suggested that ministers might play roles such as family counselor, diagnostician, therapist, and referral agent. Chang et al. ${ }^{26}$ speculated that church referrals to and from community mental health agencies (CMHCs) were not affected at all by institutional characteristics of the church. Rather, referrals from CMHCs to churches were affected by individual characteristics of the ministers, particularly the number of years in their present positions; ministers with longer job tenure were more likely to receive client referrals from CMHCs. Chang et al. speculated that minister job tenure is an indicator of the clergy's respect and influence in the community. Thus, the pastor is more likely to be seen by community mental health personnel as a credible resource. Chang et al. noted, however, that they could not rule out the possibility that these were referrals to church social service programs and not for individual pastoral counseling. Williams et al. ${ }^{13}$ asked clergy if they knew of a mental health agency to which they would feel comfortable making a referral. They also asked if Black clergy had ever referred any of their church members for help with a mental health related 
problem. They found that younger ministers were more open to referring their parishioners to specialty mental health care than older ministers. Educational level was strongly related to referral, with $85 \%$ of clergy with a college degree reporting that they had actually referred clients to mental health services.

Mollica et al. ${ }^{27}$ surveyed four groups of clergy, including Black clergy, exploring their mental health activities. Black clergy placed much importance on the use of theological beliefs in counseling (e.g., sin, guilt, forgiveness, penance, redemption, salvation). Black minsters also placed the greatest importance on the therapeutic use of such religious practices as prayer, meditation, exorcism, confession, faith healing, quoting scripture, and church attendance. Interestingly, Black ministers said that they often sought out troubled individuals rather than waiting for them to refer themselves for help. Although Black clergy did make referrals to mental health specialists, most of their referrals were to other clergy. Black clergy also indicated that they never received a referral from mental health professionals. Mollica et al.'s study is consistent with the view that there is limited contact between Black ministers and specialty mental health. Explanations for this lack of connection included such things as confusion about role-related tasks, lack of respect for clergy by mental health professionals, and philosophical/ideological conflicts between religious beliefs and psychological theories.

Mental health services researchers locate helpers along a continuum from informal help to the general medical care sector to specialty mental health care. But where is the minister located in this conceptual scheme? Should the minister be viewed as an informal helper similar to the family and friends we normally think of as comprising the social support network? Or are ministers more appropriately located within the professional helping category? Black ministers are firmly embedded within African American neighborhoods in a way that mental health professionals will never be. As such, they are almost as accessible (psychologically and physically) as most family and friends. Yet, ministers are not exactly the same as these other informal helpers. They have a level of respect, influence, and responsibility that clearly places them in their own special category. ${ }^{28}$ This ambiguity in how best to characterize the helping role of the Black minister is what this article hopes to clarify in the analyses reported below.

\section{METHOD}

\section{Sample}

The NSBA is a national probability household survey based on the distribution of the African American, noninstitutionalized population in the continental United States. Multistage-area probability sampling ensured that each Black household had an equal chance of being selected. Sampling was based on the national distribution of African Americans from the 1970 census, and 76 primary sampling units (PSUs) were selected for interviewing. After the PSUs were racially stratified, smaller geographical clusters were randomly drawn. Professionally trained interviewers visited each cluster and identified all habitable, occupied households using special screening procedures developed to identify Black-occupied homes. One member of each selected household was chosen for an interview. These sampling procedures resulted in 2,107 completed interviews, consisting of self-identified African Americans age 18 and older. The overall response rate was $67 \%$. The survey was conducted over a 7-month period in 1979 and 1980 . Overall, the sample is fairly representative of the African American population, as reported by the 
1980 census. The size and representativeness of the sample permit a systematic investigation of the heterogeneity of the adult Black population. More detailed descriptions of the sampling procedures are available in Hess $^{29}$ and Jackson. ${ }^{22}$

\section{Measures}

Personal Problem Severity. The NSBA addressed help seeking from a stress and adaptation perspective. ${ }^{30}$ The help-seeking section of the questionnaire was designed to study utilization within the concept of a "stressful episode." Respondents were asked to report one situation they had experienced that had caused them a significant amount of distress. Based on the results of analyses on pretest data, it became apparent that the meaning of the term nervous breakdown was congruent with the assumptions underlying the view of Black help seeking taken in this study. Another important goal of this study was to gather help-seeking information on as many respondents as possible. Because it was felt that only a minority of the sample would have ever experienced a personal problem so serious that it elicited feelings of a nervous breakdown, the initial nervous breakdown item was followed by a series of questions, roughly ordered in decreasing levels of impairment. The specific items that were used to elicit information about personal problems and coping responses were the following: (1) When problems have come up, has there ever been a time when you were about at the point of a nervous breakdown? (2) (If answered no to the above question) Has there ever been a time when you had a personal problem where you felt so nervous you couldn't do much of anything? (3) (If answered no to \#2) Has there ever been a time when you felt down and depressed, so low that you felt you just couldn't get going? (4) (If answered no to \#3) Have you ever had a personal problem you could not handle by yourself? (5) (If answered no to \#4) Have you ever had what you thought was a serious personal problem that you tried to handle by yourself?

Personal Problem Type. All respondents who said they had experienced a problem were asked the following question: "Thinking about the last time you felt this way, what was the problem about? You don't have to go into any great detail, I'd just like some general idea of what the problem was about." This question was designed to ascertain how the respondent conceptualized the nature of the distress experienced. For analysis purposes, responses to this question were categorized into five problem categories: (1) physical health problems, (2) interpersonal difficulties (marital problems, problems with the opposite sex, and interpersonal relationships in general), (3) emotional adjustment problems, (4) death of a loved one, and (5) economic difficulties. Respondents were coded yes on the problem-type variable if they reported that particular type of problem across multiple mentions and no otherwise. For example, if a respondent indicated that she had an economic problem and an emotional problem, she would be scored yes on economic and emotional and no on all the others. If another respondent said that he had an economic problem and then mentioned another economic problem, he would be scored yes on economic problems and no on all the others.

Professional Help Use. The use of professional help was measured in the following manner. If respondents had experienced a problem, they were presented with a list of professional helping facilities and asked if they had gone to any of the places listed for help with their personal problems. The question read as follows: "Here is a list of places a person might go to get help with a problem like the one you had. Please tell me if you went to any of these places for help with the problem." The professional helper list included the 
following places: hospital emergency room, medical clinic, social service or welfare agency, mental health center, private therapist (psychiatrist, psychologist), doctor's office, minister, lawyer, police, school, and employment agency. Although we focus on clergy as a source of help, we include one other source of help category for comparison purposes. This second category combines all nonclergy sources into a single group.

Prior analyses have focused almost exclusively on analyses of clergy as the first help source mentioned by respondents. Previous work has not taken full advantage of the fact that respondents in the NSBA were allowed to mention up to four sources from which they sought help. In this article, we take advantage of the multiple mentions and two previously unanalyzed questions on the sequence of professional help sources contacted to create new and more comprehensive utilization variables. ${ }^{\dagger}$ This allows us to conduct a more complex and accurate investigation of the role Black pastors play in the helpseeking process of African Americans. In addition to the minister utilization variables, we also explore responses to the following items: (1) "What did the person you saw do to try to help you with your problem?" and (2) "Would you go back again if you needed help?"

There has been only one prior paper on minister use in which multivariate analyses have been employed. ${ }^{12}$ That study, however, used an analytical technique that limited simultaneous consideration to a maximum of four dichotomous variables. In these analyses, we use multivariate logistic regression to increase the number of variables used to simultaneously predict the use of clergy.

\section{RESULTS}

The major research questions for these analyses are fourfold. First, what characteristics are associated with seeking help from clergy? Second, what types of problems are predictive of whether individuals will seek help from clergy? Third, given that someone goes to the clergy for help with a problem, how many then go on to seek help from another source? Moreover, how does this compare to persons who seek help from another source first? Finally, what type of help is received by those who go to the clergy, and are they satisfied with that help?

We approach the answer to the first question in two ways. First, we examine the bivariate associations between the sociodemographic variables, problem types, problem severity, and seeking help from the clergy. The results from these analyses are shown in Table 1. In this table, we report the percentages reporting seeking help from the clergy by levels of the different variables. According to this table, the only sociodemographic characteristic that is associated with seeking help from clergy is sex. In that regard, more women report seeking such help than men. In terms of problem types, two variables are significantly associated with clergy help. The first, economic problems, is associated such that those reporting economic problems were less likely to seek clergy help. In contrast, those with problems relating to death or bereavement were more likely to seek help from the clergy than those who reported no such problems. This finding is in consonance with our aforementioned discussion of the ways in which the clergy are best able to help their parishion-

\footnotetext{
†If respondents had mentioned contacting more than one professional help source, they were asked two additional questions. The first item read, "Of all the places you went to, which place did you go to first?" The second question asked, "Which place did you go to last?" These questions allow us to pinpoint more precisely the actual sequencing or pathways of help seeking in the National Survey of Black Americans.
} 


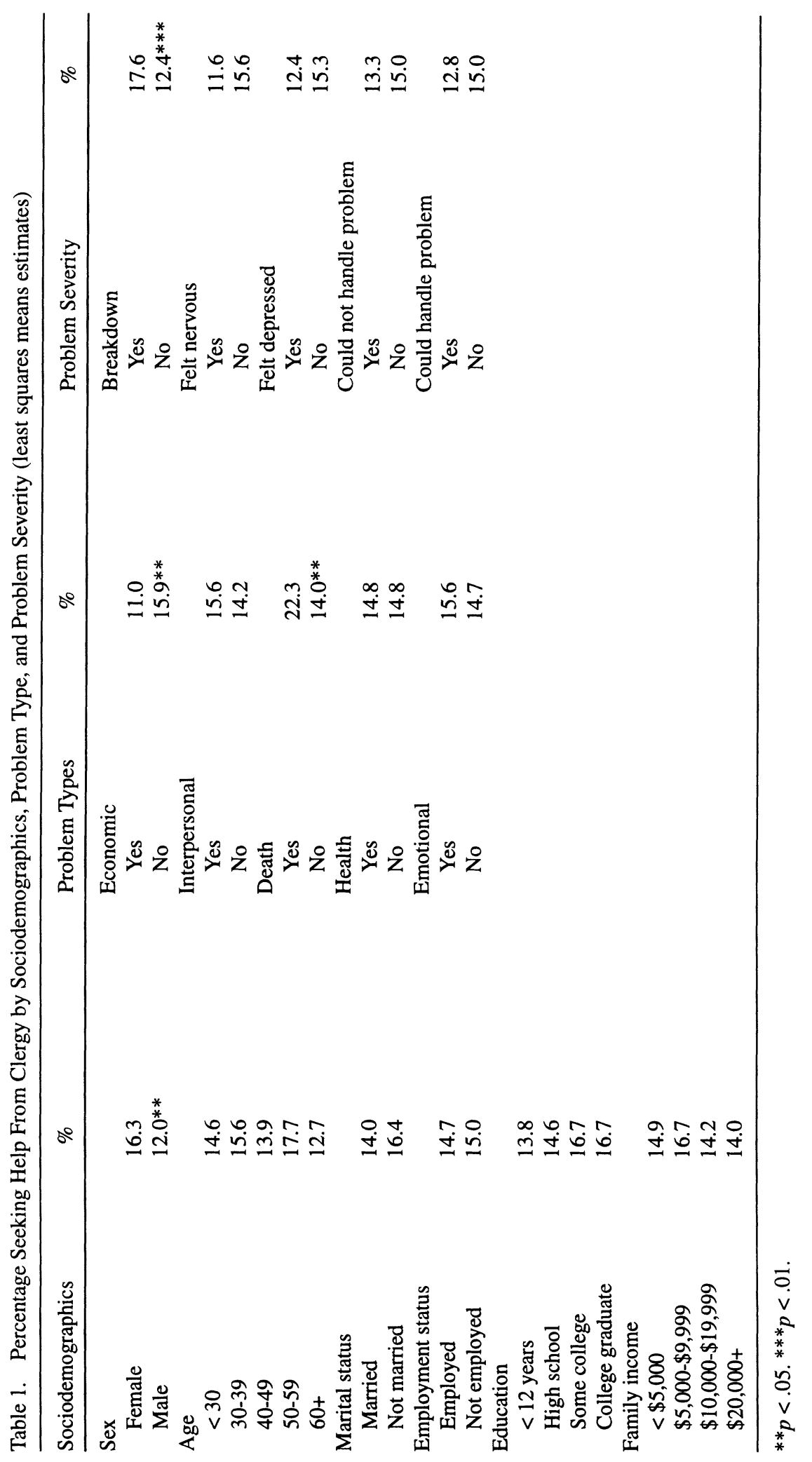


Table 2. Estimated Net Effects of Sociodemographic, Problem Type, and Problem Severity Variables on Seeking Help From Clergy (logistic regression estimates; $N=1,107$ )

\begin{tabular}{|c|c|c|c|}
\hline & Model 1 & Model 2 & Model 3 \\
\hline \multicolumn{4}{|l|}{ Sociodemographics } \\
\hline Female & 1.238 & 1.164 & 1.040 \\
\hline Married & .834 & .848 & .859 \\
\hline Employed & .890 & .917 & .957 \\
\hline \multicolumn{4}{|l|}{ Age } \\
\hline \multicolumn{4}{|l|}{$<30$ (reference) } \\
\hline $30-39$ & 1.056 & 1.030 & 1.029 \\
\hline $40-49$ & 1.104 & 1.019 & 1.009 \\
\hline $50-59$ & 1.447 & 1.377 & 1.354 \\
\hline $60+$ & .978 & .886 & .877 \\
\hline \multicolumn{4}{|l|}{ Education } \\
\hline \multicolumn{4}{|l|}{$<12$ years (reference) } \\
\hline High school & 1.062 & 1.066 & 1.101 \\
\hline Some college & 1.460 & 1.389 & 1.474 \\
\hline College graduate & 1.674 & 1.615 & $1.778 *$ \\
\hline \multicolumn{4}{|l|}{ Family income } \\
\hline \multicolumn{4}{|l|}{$<5,000$ (reference) } \\
\hline$\$ 5,000-\$ 9,999$ & 1.239 & 1.145 & 1.114 \\
\hline$\$ 10,000-\$ 19,999$ & 1.065 & 1.019 & 1.020 \\
\hline$\$ 20,000+$ & 1.150 & 1.016 & 1.015 \\
\hline \multicolumn{4}{|l|}{ Problem type } \\
\hline \multicolumn{4}{|l|}{ Economic (reference) } \\
\hline Death & - & $3.329 * * * *$ & $3.600 * * * *$ \\
\hline Interpersonal & - & $1.972 * *$ & $1.989 * *$ \\
\hline Health & - & 1.764 & $1.842^{*}$ \\
\hline Emotional & - & 1.888 & 1.872 \\
\hline Missing & - & 1.420 & 1.499 \\
\hline \multirow{2}{*}{\multicolumn{4}{|c|}{$\begin{array}{l}\text { Problem severity } \\
\text { Felt nervous (reference) }\end{array}$}} \\
\hline & & & \\
\hline Breakdown & - & - & $1.907 * *$ \\
\hline Felt depressed & - & - & 1.148 \\
\hline Could not handle problem & - & - & 1.254 \\
\hline Could handle problem & - & - & 1.143 \\
\hline Intercept & -2.055 & -2.503 & -2.873 \\
\hline Chi-square & 9.36 & 22.37 & 31.85 \\
\hline Pseudo $R^{2}$ & .008 & .020 & .028 \\
\hline
\end{tabular}

NOTE: Odds ratios are displayed. Models contain only those who reported one mention for the problem-type variable.

${ }^{*} p<.10 .{ }^{* *} p<.05 .{ }^{* * * *} p<.001$.

ers. Finally, the only problem severity variable that was associated with seeking clergy help is nervous breakdown. The association is such that those who experienced a nervous breakdown were more likely than others to have sought help from the clergy.

Next, we estimated the net effects of each of these variables on seeking help from clergy using multivariate logistic regression. It is important to note that the models omit all respondents who report more than one problem type. If we were to include those who 
Table 3. Percentages of Overall Number of Help Sources and Number of Sources by Whether the Clergy Was a Source

\begin{tabular}{lccc}
\hline & & \multicolumn{2}{c}{ Sought Help From 1+ Sources } \\
\cline { 3 - 4 } Number of Sources & $\%$ & Clergy and Others & No Clergy \\
\hline 0 & 52.3 & - & - \\
1 & 27.4 & 48.98 & 61.29 \\
2 & 11.3 & 22.45 & 24.19 \\
3 & 5.1 & 15.31 & 8.53 \\
4 & 3.9 & 13.27 & 5.99 \\
Chi-square & & & $18.229^{* * * *}$ \\
\hline
\end{tabular}

$* * * * p<.001$.

report more than one problem, there would be some overlap between the problem type categories. Furthermore, we include a variable among the problem types called missing problem. The variable is coded 1 if the respondent did not report the nature of the problem and is coded 0 otherwise. By including this variable, we can be sure that the comparisons between the various problem types and the economics problem type are uncontaminated.

The results from these analyses are shown in Table 2 . Model 1 in this table includes only the sociodemographic variables, model 2 includes the problem types, and model 3 adds the levels of problem severity. According to the results in the first model, none of the sociodemographic predictors has any effect on seeking help from the clergy. Turning to the effects of problem types in model 2, we see several interesting results. According to these odds ratios, respondents who reported problems associated with death or bereavement were more than three times as likely as those reporting economic problems to have sought help from clergy. Similarly, those reporting interpersonal problems were about twice as likely as those with economic problems to report seeking clergy help. In short, it appears that although sociodemographic variables are not strong predictors of whether African Americans seek help from clergy, the type of problem encountered does have a substantial influence.

The final model in this table includes the controls for problem severity. We chose "felt nervous" as the reference category here due to the fact that in the bivariate analyses, those who reported this level of problem severity were the least likely to seek the clergy for help. According to these results, those who reported suffering a nervous breakdown were more likely to seek help from the clergy than those who felt nervous. This finding parallels the finding in the bivariate analyses that indicates that respondents reporting a breakdown seek help from clergy more often than all other groups.

The next set of research questions deals with whether those seeking help from the clergy go on to seek help from other sources. The first step in answering this question is to determine what percentage of respondents report seeking help from the church versus other organizations and how that relates to the number of sources from which the respondent sought help overall. Table 3 presents this first step. The first column of the table gives the percentage distribution for the numbers of sources from which respondents sought help. According to the percentages, a majority of respondents report seeking help from no sources. Of those who did seek help, most sought it from only one source. The second two columns list the percentage distributions of the number of sources from which respondents sought help by whether one of the sources was the clergy. Of those who sought help 
Table 4. Percentage of Respondents Seeking Help From More Than One Source by Whether the Church Was the First Source of Help, by Problem Type and Severity (least squares means estimates)

\begin{tabular}{|c|c|c|c|}
\hline & $>1$ Source & & $>1$ Source \\
\hline \multicolumn{4}{|l|}{ All problems $(n=612)$} \\
\hline Church first & 29.46 & & \\
\hline Other first & $46.38 * * * *$ & & \\
\hline Problem types & \multicolumn{3}{|c|}{ Problem severity } \\
\hline Economic $(n=130)$ & \multicolumn{3}{|c|}{ Breakdown $(n=109)$} \\
\hline Church first & 27.78 & Church first & 37.50 \\
\hline Other first & 42.86 & Other first & $51.68^{* *}$ \\
\hline Interpersonal $(n=280)$ & \multicolumn{3}{|c|}{ Felt nervous $(n=104)$} \\
\hline Church first & 42.86 & Church first & 22.72 \\
\hline Other first & 43.81 & Other first & $44.44^{*}$ \\
\hline Death $(n=51)$ & \multicolumn{3}{|c|}{ Felt depressed $(n=225)$} \\
\hline Church first & 19.05 & Church first & 12.00 \\
\hline Other first & $60.00 * * *$ & Other first & $37.10^{* *}$ \\
\hline Health $(n=134)$ & \multicolumn{3}{|c|}{ Couldn't handle $(n=258)$} \\
\hline Church first & 10.00 & Church first & 28.57 \\
\hline Other first & $58.87 * * *$ & Other first & 33.33 \\
\hline Emotional $(n=54)$ & \multicolumn{3}{|c|}{ Could handle $(n=626)$} \\
\hline Church first & 11.11 & Church first & 36.36 \\
\hline Other first & $51.11 * *$ & Other first & 44.11 \\
\hline
\end{tabular}

${ }^{* *} p<.05 .{ }^{* * *} p<.01 .{ }^{* * * *} p<.001$.

from clergy, almost $50 \%$ sought help only from that source, whereas $61 \%$ of those who did not seek help from the clergy sought help from only one source. In contrast, $13 \%$ of clergy help seekers sought help from a total of four organizations, but only $6 \%$ of those who did not seek such help went to four organizations. Comparing the two distributions overall, it appears that those respondents who sought help from the clergy were more likely to seek help from other organizations. The significant chi-square statistic at the bottom of the table supports this conclusion.

Table 3 does not really answer the question of whether respondents who go first to their ministers are more likely to go elsewhere when compared to those who go to nonclergy initially. Table 4 attempts to answer this question. Of all those who sought help, $21.1 \%$ went to the church first, and $78.9 \%$ went somewhere else first. According to Table 4, among all respondents reporting a problem, of those who went to the church first, $29.5 \%$ then went somewhere else, whereas $46.4 \%$ of those who went for nonclergy help continued to seek other sources. The difference between the means is significant, indicating that compared to those who first sought other sources of support, respondents who first used the clergy were less likely to go to any other source. The remainder of this table presents the same analysis but is sorted according to problem type and problem severity. Across all problem types and severity, the pattern is the same: Those who seek support from the clergy first are less likely to then seek other types of professional help. This pattern is especially pronounced for three problem types: death, health, and emotional. In terms of problem severity, the largest differences occur in the nervous breakdown and "felt depressed" groups. 
Table 5. Type of Help Received From Clergy

\begin{tabular}{lc}
\hline & $\begin{array}{c}\text { \% of Respondents } \\
\text { Receiving Help }\end{array}$ \\
\hline Prayed/read Bible/told to pray & 41.3 \\
Listened/let me talk & 33.7 \\
General advice & 16.8 \\
Gave respondent medicine or treatment & 14.3 \\
Comfort/sympathy/consolation & 13.3 \\
Took action of/for respondent & 7.1 \\
Money & 2.0 \\
Advice specific to problem & 1.5 \\
Unspecified help & 1.5 \\
Helper was not helpful & 1.0 \\
Other material aid & 0.5 \\
Other help & 0.5 \\
Referred to other clergy & 0.5 \\
Referred to church & 0.5 \\
\hline
\end{tabular}

Table 6. Mean Levels of Satisfaction and Proclivity to Refer Others to the Same Source by Source of Help (least squares means estimates)

\begin{tabular}{lccccc}
\hline & \multicolumn{2}{c}{1 Source } & & \multicolumn{2}{c}{$>1$ Source } \\
\cline { 2 - 3 } \cline { 6 - 7 } & Satisfaction & Would Refer & & Satisfaction & Would Refer \\
\hline Clergy help & 3.73 & .89 & & 3.64 & .83 \\
Other help & $3.24^{* * * *}$ & $.78^{* *}$ & & $3.25^{* *}$ & .82 \\
\hline
\end{tabular}

${ }^{* *} p<.05 .{ }^{* * * *} p<.001$.

The final step in the analyses is to determine what type of help was received when respondents went to the clergy for help. Because respondents could have reported receiving more than one type of help, we have arranged this table so that each figure indicates the percentage of respondents who went to the clergy for help and received that type of help. Consequently, the percentages will not sum to $100 \%$. According to Table 5, as one might expect, the most common type of help given was related to religious activities. Following the religious aspect of help, the other most common types tend to fall into the emotional types of support. Seven percent mentioned that ministers took action on their behalf. This helping response reflects the fact that historically, Black clergy have played a strong advocacy role on a large number of issues, not exclusively spiritual. ${ }^{31}$ We should also note that although not a frequent response, some of the ministers did offer material aid in the form of informal monetary assistance.

Table 6 shows mean levels of satisfaction with help received and proclivity to refer others with a similar problem to the same source. Due to the way in which these questions were asked, we have divided the analyses into two groups: those who sought help from one source and those who sought help from more than one source. In the NSBA, the questions about satisfaction and referral are asked only for the last source from which help was 
sought. Consequently, respondents could have sought help from the church and then from a social agency, but the satisfaction question would be geared only toward the second source. As such, in the more than one source group, satisfaction ratings may be confounded by feelings toward earlier sources of support that are not measured here. To help overcome this limitation, we make the division in the sample noted above.

Among those who sought help from only one source, the analyses indicate that those who used the clergy were significantly more satisfied with that support than were those who used some other source. Similarly, those who sought clergy support were also more likely to refer others to the same source than were respondents who sought another type of help. For those who sought help from more than one source, the results are not as evident. Although clergy help seekers rated their experience as more satisfactory, they were no more likely to refer others to the same source.

\section{DISCUSSION}

Among the many public health roles that Levin ${ }^{18}$ outlined for African American ministers, those of counselor, diagnostician, and referral agent have been most emphasized in the literature. Studies by Chang et al., ${ }^{26}$ Caldwell et al., ${ }^{14}$ and Mollica et al., ${ }^{27}$ for example, suggest that there are indeed Black clergy who are making referrals to mental health professionals. But there are also indications in the literature that some African American pastors may not be that comfortable with referring church members to mental health professionals. Bentz ${ }^{17}$ found that while ministers paid attention to the signs of mental illness, this perspective did not translate into any actual referrals, especially among the lesseducated ministers. Chang et al. ${ }^{26}$ found that the pattern of referrals made and received by Black clergy revealed an incongruence between the two groups. They concluded that there was, at best, a "loose coupling" of these two systems and that African American ministers and mental health workers operated within two different environments.

One way to characterize this situation is professional perspectives in conflict. ${ }^{32}$ There are a variety of ways to characterize psychological distress and problematic behavior. ${ }^{33}$ While there is certainly some overlap between ministers and mental health professionals, it is also clear that these two groups often operate according to very different conceptual frameworks, assumptions, and values. ${ }^{21,34}$ For example, Wright et al. found that while clergy saw stress and unhealthy family relationships as causes of mental illness, they also endorsed such things as not having the right relationship with God, unconfessed sin, and stunted spiritual growth. Another area of disagreement was the fact that clergy saw pastoral counselors as more qualified than mental health professionals because pastoral counselors treat the "whole" person; the other mental health professions focus only on the mind and body, thus ignoring spiritual issues. To the extent that African American pastors feel that the Western biomedical conceptualization of mental health is inappropriate, ineffective, or limited, we would not expect them to refer parishioners for mental health treatment.

The picture painted by the results presented here is complex. It is clear that powerful social and cultural forces pull African Americans toward Black ministers for counseling. We suspect that there are even stronger forces (e.g., stigma, cost, mistrust, a philosophy of self-reliance) pushing African Americans away from specialty mental health care. On one hand, African American ministers are highly accessible and, as a result, do carry a tremendous amount of the therapeutic load for African Americans seeking help for personal problems. Furthermore, our data show that the vast majority of Black help seekers are sat- 
isfied with the help they receive from their pastors. On the other hand, as shown in Table 4, compared to other sources of professional help, Black ministers tend to impede access to other forms of specialty mental health care.

It is interesting to speculate about why African Americans who do go for professional help in emotionally difficult times eventually turn also to ministers, but those who go to the minister first go to very few additional places. It could be that when African Americans contact the pastor, they receive exactly what they need and, as a result, feel no motivation to turn elsewhere. This line of reasoning would explain both patterns. In the first instance, people search for help but are not satisfied with the assistance offered. As a result, they keep searching until they end up seeking help from their minister, where they find the comfort they are looking for. In the second instance, people contact the minister first, get the help they need, and, as a result, have no need to search further. Our finding that blacks who used ministers were very satisfied with the help they received is consistent with this conclusion. Furthermore, the fact that there was an even stronger relationship between this help-seeking pattern (contacting one's minister first and then going nowhere else) and the types of problems best handled within a religious framework (e.g., bereavement) provides even stronger evidence in support of this conclusion.

The kind of informal, indigenous help provided by ministers is extremely important in alleviating the distress that African Americans experience. In fact, this kind of assistance has been largely responsible for the survival and advancement of African Americans in the face of racism and discrimination. ${ }^{31}$ But there are two sides to social support networks. While there are times when such help is necessary and appropriate, there are also situations when we want informal helpers to "step aside" and make a referral to the formal health care system. Ideally, network members such as ministers would be able to recognize and define serious medical conditions so that at the appropriate point, they could switch from a "lay treatment" to a "lay referral" mode. ${ }^{35}$ The impact of relatively dense, cohesive social networks on the use of professional resources has received considerable attention in help-seeking research. ${ }^{36}$ In such networks, people tend to know and trust one another. As a result, helping transactions such as folk remedies and indigenous therapies tend to be dispensed in reciprocal arrangements that can substantially reduce the perceived need to use professional services. This analysis provides evidence that African American ministers operate more in this manner than as a bridge to mental health care.

However, we think the assumption that Black ministers should operate primarily as referral agents for mental health practitioners should be thought through more carefully, particularly within the context of the present findings. For example, the data reported here show that African Americans are most likely to contact ministers for help with death problems. ${ }^{37}$ Thus, Black s turn to ministers precisely for the kinds of problems for which it would appear that ministers are most qualified to handle through the use of religion. This finding is not surprising, given that one of the primary functions of religion is to provide frameworks through which individuals can come to find meaning and understanding in suffering and death. ${ }^{38-41}$ Given this important function of religion, many respondents who have faced a recent death will go to their ministers to find meaning and comfort. Koenig ${ }^{42}$ emphasized the importance of religion in the grieving process and provided some evidence to support the notion that persons who use religion to cope with death tend to adapt more quickly. In one study, Cook and Wimberly ${ }^{43}$ reported that respondents who tried to cope actively with a child's death also reported greater religious commitment over time. More recently, McIntosh et al. found that parents who engaged in more religious activity adapted better to the loss of a child. Moreover, through this better adaptation, religious parents also had better mental health outcomes over an 18-month follow-up. In sum, the- 
ory and evidence support the conclusion that religion and ministers are important sources of support needed by those facing the distress caused by death.

Clearly, Black ministers are qualified to treat such personal problems of living. Yet, important questions remain. We know that some death problems and grief reactions can be extremely serious. For example, other analyses of the $\mathrm{NSBA}^{30}$ have shown that people experiencing death problems also evidence the highest levels of distress, as measured by the number and frequency of symptoms. Similarly, data from a follow-up study of the NSBA indicate that $10 \%$ of those with death problems also meet DSM-III-R criteria for major depression. Such findings present an interesting practical dilemma. It is on this problem that mental health education efforts should focus.

The findings reported here also raise complicated questions about the public's view of professional expertise and responsibility. ${ }^{18}$ While there is general consensus among African Americans that people should seek professional help for "physical health" problems, this is not necessarily the case for personal, interpersonal, and emotional problems. As a result, the types of problems studied here are much more likely to be taken to alternative, nonmedical professionals such as ministers. From this standpoint, one must ask why we should expect Black ministers to automatically refer distressed church members for professional mental health help. Inherent in the view of Black ministers as referral agents is the assumption that they are facing conditions and syndromes they are not qualified to address. While this may be true in some cases, it is not always clear who-ministers or mental health workers-is most qualified to treat the kinds of personal problems African Americans experience.

While we were not able to discern much about the degree to which Black ministers are working as diagnosticians, there is a link between this role and that of the referral agent. To the extent that Black clergy are able to identify cases of disorders such as major depression, schizophrenia, or manic depressive illness, we assume that they should refer such conditions for the appropriate mental heath treatment intervention. It may be the case that Black ministers feel unprepared to identify the presence of such disorders. Certainly, adopting the role of diagnostician means that Black clergy will have to have a good working familiarity with the $D S M-I V$, for example. It also means helping ministers to develop an openness to incorporating some Western medical-psychiatric perspectives on behavior and distress. This is the only way that African American ministers will be able to discriminate between where their domain ends and where the domain of the mental health professional begins. Once Black ministers are able to identify the clinical severity of the conditions they see, they may begin to make more referrals. Health educators should look to churches as settings for educating African American ministers about disorders such as depression, bipolar disorder (manic-depressive illness), anxiety, phobias, and schizophrenia. ${ }^{13,18,45}$

In addition to enhancing the diagnostician role for Black ministers, these data indicate a need for mental health education programs targeted toward African American church members as well. Using depression as just one example, we feel that much can be gained by exposing more African Americans to the signs and symptoms of this debilitating disorder. A recent national survey of attitudes toward depression among African Americans found, for example, a very low awareness of depressive symptomatology. ${ }^{46}$ Specifically, only $26 \%$ of those questioned knew that a change in eating habits was an indicator of depression-and this was the symptom with the highest percentage of recognition. Interestingly, $63 \%$ of the African American respondents conceptualized depression as a personal weakness; only $31 \%$ felt depression was a health problem. More than one-third (36\%) said that they would recommend that a friend seek help from a minister for depres- 
sion, and $60 \%$ believed that prayer and faith were the most successful methods of treating depression. These findings make it clear that the majority of African Americans conceptualize personal distress within a religious framework rather than the perspective employed by mental health professionals. Thus, it is not surprising that Blacks are significantly less likely than Whites to seek professional help. ${ }^{47-49}$

The community mental health movement can be seen as an attempt by the mental health professions to assume responsibility for behavioral problems that historically had been viewed by the public as falling within the moral as opposed to the medical realm. ${ }^{33}$ Moreover, this shift in responsibility seems to have been based as much on ideological beliefs about the most humane forms of treatment and individual rights as it was on the effectiveness of the intervention techniques. ${ }^{50,51}$ Early studies of the public's conceptualization of emotional and mental illness revealed very little overlap between the average citizen and mental health professionals. ${ }^{52-54}$ While there clearly has been an increase in the public's acceptance of the mental health professionals' perspective over the years, ${ }^{37}$ many Americans do not think that emotional upset falls within the expertise of the mental health community. Our data suggest that for a substantial segment of the African American population, particularly among the religious, things are still where they were in the early days of the community mental health movement. As such, it makes perfect sense that Blacks would consult ministers before considering a mental health professional. Couple this conflict of perspectives with the high levels of distrust African Americans have for health and medical care, and we are led to the conclusion that substantial barriers must be overcome before we reach the goal of these two professions working together for the betterment of African Americans in need. ${ }^{21}$

\section{Study Weaknesses}

Although this study advances our understanding of the role of the clergy in the helpseeking process, it nevertheless has several weaknesses that limit its ability to make definitive statements regarding these issues. First, the data are from the first wave of the NSBA and, as such, were collected almost two decades ago. Consequently, the patterns we see in these data may no longer accurately reflect the behaviors of help seekers or the clergy. Indeed, as mental health disorders have become increasingly visible and seen to exist in the realm of medical practitioners, clergy may be more likely to refer others now than they were in the past. A second problem with the data concerns the response rate for the sample. The first wave of the NSBA had a response rate of only $67 \%$, which is low for a survey that collects data using face-to-face interviews. As such, the results may be biased in ways that we cannot discern.

A third weakness concerns our assumption that the clergy from whom respondents sought help were also African American. With these data, we are unable to determine whether this is indeed the case. However, according to Roof and McKinney, ${ }^{55}$ current evidence supports the notion that the religious life of African Americans takes place, for the most part, in the context of the African American church. As these authors note, "Of all the divisions among churches, the color line is the most rigid and enduring" (p. 138). Moreover, they estimate that $85 \%$ of all Black Protestants are members of African American congregations. Nevertheless, if it is the case that some of the respondents who sought help from clergy did not go to African American clergy, such information would be important for understanding the issues at hand. Unfortunately, we have no way of knowing whether this happened and, if so, what ramifications it had. 
A final weakness concerns our measurement of referral. We measure that construct based on whether respondents went to more than one organization with the assumption that the first organization referred the respondent to another. This assumption is untestable with these data. Furthermore, because we do not ask clergy directly about their referral practices, our rates of referral by those individuals may be biased.

\section{Recommendations for Future Research}

This article has allowed us to pinpoint more precisely where mental health educational efforts should be targeted. As a result, we make the following recommendations. There is a clear need for more empirical research on the training needs of the Black clergy. Larson et al. concluded that research on pastoral care is lacking, and what little there is suffers from numerous methodological deficiencies. The same can be said for studies of African American pastoral counseling. We need to know how many Black ministers have received training in pastoral care. We also need to know more about how prepared Black ministers feel to perform therapeutic interventions linked to psychiatric conditions. More than anything else, this article points to the need for more direct contact and information exchange between mental health workers and African American clergy. It is inappropriate to assume that only Black ministers need to learn more about mental health. Mental heath practitioners need to learn more about the spiritual and religious beliefs of Black clergy.

More than any other influence on the help-seeking behaviors of African Americans, ministers hold the most potential for opening a wider pathway between the Black community and specialty mental health care. Much remains to be done, however, before we can take full advantage of this potential, and public mental health education must provide the crucial impetus to initiate this change. It is time that we mount more aggressive mental health education efforts designed to bring the Black clergy and the mental health professional closer together. Once this is accomplished, we stand a much better chance of increasing access for African Americans in need of professional care. The African American minister is the best hope for bridging the gap between the Black community and specialty mental health. But much work remains before Black ministers can fulfill this linking role. It is hoped that the thoughts and opinions expressed here will motivate both ministers and mental health practitioners to begin the difficult but necessary task of educating each other about what needs to be done to ensure quality care for African Americans in search of spiritual and emotional assistance.

\section{References}

1. Brown DR, Eaton WW, Sussman L: Racial differences in prevalence of phobic disorders. JNerv Ment Dis 178:434-441, 1990.

2. Kessler R, McGonagle K, Zhao S, Nelson C, Hughes M, Eshleman S, Wittchen H, Kendler K: Lifetime and 12-month prevalence of DSM-III-R psychiatric disorders in the United States: Results from the National Comorbidity Survey. Arch Gen Psychiatry 51:8-19, 1994.

3. Robins L, Regier D: Psychiatric Disorders in America: The Epidemiologic Catchment Area Study. New York, Free Press, 1991.

4. Somervell PD, Leaf PJ, Weissman MM, Blazer DG, Bruce ML: The prevalence of major depression in Black and White adults in five United States communities. Am J Epidemiol 130(4):725-735, 1989. 
5. Kessler RC, Berglund PA, Zhao S, Leaf PJ, Bruce ML, et al.: The 12-month prevalence and correlates of serious mental illness (SMI), in Manderscheid RW, Sonnenschein MA (eds.): Mental Health, United States, 1996 (DHHS Pub. No. [SMA] 96-3098). Washington, DC, Government Printing Office, 1996.

6. Blazer DG, Kessler RC, McGonagle KA, Swartz MS: The prevalence and distribution of major depression in a national community sample: The National Comorbidity Survey. Am J Psychiatry 151(7):979-986, 1994.

7. Magee WJ, Eaton WW, Wittchen H, McGonagle KA, Kessler RC: Agoraphobia, simple phobia, and social phobia in the National Comorbidity Survey. Arch Gen Psychiatry 53:159-168, 1996.

8. Magee WT: Psychological Predictors of Agoraphobia, Simple Phobia, and Social Phobia Onset in a U.S. National Sample. Unpublished dissertation, Department of Sociology, University of Michigan, 1993.

9. Neighbors HW, Jackson JS: Mental Health in Black America. Thousand Oaks, CA, Sage, 1996.

10. Neighbors HW, Jackson JS: The use of informal and formal help: Four patterns of illness behavior in the Black community. Am J Community Psychol 12(6):629-644, 1984.

11. Hicks HB: Images of the Black Preacher: The Man Nobody Knows. Valley Forge, Judson Press, 1977.

12. Neighbors HW: Mental health, in Jackson JS (ed.): Life in Black America. Newbury Park, CA, Sage, 1991.

13. Williams DR, Griffith EEH, Young JL, Collins C, Dodson J: Structure and provision of services in New Haven Black churches. Cult Divers Ment Health, in press.

14. Caldwell CH, Greene AD, Billingsley A: Family support programs in Black churches: A new look at old functions, in Kagan SL, Weissbourd B (eds.): Putting Families First: America's Family Support Movement and the Challenge of Change. San Francisco, Jossey-Bass, 1994, pp. 137-160.

15. Taylor RJ, Chatters LM: Church-based informal support among elderly Blacks. The Gerontologist 26:637-642, 1986.

16. Taylor RJ, Chatters LM: Church members as a source of informal social support. Rev Religious Res 30:193-203, 1988.

17. Bentz WK: The clergyman's role in community mental health. JReligion Health 9:7-14, 1970.

18. Levin J: Roles for the Black pastor in preventive medicine. Pastoral Psychol 35(2):94-103, 1986.

19. Weaver AJ: Has there been a failure to prepare and support parish-based clergy in their role as frontline community mental health workers? A review. J Pastoral Care 49(2):129-147, 1995.

20. Wright PG, Moreau ME, Haley GM: The clergy's attitudes about mental illness, counseling, and the helping professions. Can J Community Mental Health 1:71-80, 1982.

21. Larson DB, Hohmann AA, Kessler LG, Meador KG, Boyd JH, McSherry E: The couch and the cloth: The need for linkage. Hosp Community Psychiatry 39(10):1064-1069, 1988.

22. Jackson JS (ed.): Life in Black America. Newbury Park, CA, Sage, 1991.

23. Taylor RJ, Chatters LM, Jayakody R, Levin JS: Black and White differences in religious participation: A multisample comparison. J Sci Study Rel 35:403-410, 1996.

24. Taylor RJ, Chatters LM: Religious life, in Jackson JS (ed.): Life in Black America. Newbury Park, CA, Sage, 1991, pp. 105-123.

25. Johnson W, Neighbors HW, Boone A: Perceptions of Mental Health and Mental Illness Among Urban African Americans. Paper presented at the annual meeting of the National Association of Social Workers, Cleveland, OH, November, 1996.

26. Chang PMY, Williams DR, Griffith EEH, Young J: Church-agency relationships in the Black community. Nonprofit Volunteer Sector Q 23(2):91-105, 1994.

27. Mollica RF, Streets FJ, Boscarino J, Redlich FC: A community study of formal pastoral counseling activities of the clergy. Am J Psychiatry 143(3):323-328, 1986.

28. Tuggle MB: New insights and challenges about churches as intervention sites to reach the African American community with health information. J Nat Med Assoc 87(suppl.):635-637, 1995. 
29. Hess I: Sampling for Social Research Surveys: 1947-1980. Ann Arbor, Institute for Social Research, University of Michigan, 1985.

30. Neighbors HW, Jackson JS, Bowman PJ, Gurin G: Stress, coping and Black mental health: Preliminary findings from a national study. Prev Human Ser 2(3):5-29, 1983.

31. Moore T: The African-American church: A source of empowerment, mutual help, and social change, in Pargament KI, Maton KI, Hess RE (eds.): Religion and Prevention in Mental Health: Research, Vision and Action. New York, Haworth, 1992, pp. 237-257.

32. Price R: Abnormal Behavior: Perspectives in Conflict. Chicago, Holt, Rinehart \& Winston, 1972.

33. Mechanic D: Medical Sociology (2nd ed.). New York, Free Press, 1978.

34. Gottlieb JF, Olfson M: Current referral practices of mental health providers. Hosp Community Psychiatry 38(11):1171-1181, 1987.

35. Friedson E: Client control of medical practice. Am J Sociology 65:374-382, 1960.

36. Horwitz A: Family, kin, and friend networks in psychiatric help seeking. Soc Sci Med 12:297304, 1978.

37. Veroff J, Kulka RA, Douvan E: Mental Health in America: Patterns of Help-Seeking From 1957 to 1976. New York, Basic Books, 1981.

38. Berger P: The Sacred Canopy: Elements of a Sociological Theory of Religion. New York, Doubleday, 1967.

39. Roberts KA: Religion in Sociological Perspective. Homewood, IL, Dorsey, 1984.

40. Wuthnow R: Rediscovering the Sacred: Perspectives on Religion in Contemporary Society. Grand Rapids, MI, William B. Eerdmans, 1992.

41. Beit-Hallahmi B, Argyle M: The Psychology of Religious Behavior, Belief and Experience. New York, Routledge \& Kegan Paul, 1997.

42. Koenig HG: Aging and God: Spiritual Pathways to Mental Health in Midlife and Later Years. New York, Haworth Pastoral Press, 1994.

43. Cook JA, Wimberly DW: If I should die before I wake: Religious commitment and adjustment to the death of a child. J Sci Study Rel 22(3):222-238, 1983.

44. McIntosh DN, Silver RC, Wortman CB: Religions's role in adjustment to a negative life event: Coping with the loss of a child. J Personality Soc Psychol 65:812-821, 1993.

45. Eng E, Hatch JW: Networking between agencies and Black churches: The lay health advisor model, in Pargament KI, Maton KI, Hess RE (eds.): Religion and Prevention in Mental Health: Research, Vision, and Action. New York, Haworth, 1992, pp. 293-316.

46. National Mental Health Association: Breaking Out of the Box: American Attitudes About Clinical Depression and Its Treatment. Alexandria, VA, National Mental Health Association, 1996.

47. Gallo JJ, Marino S, Ford D, Anthony JC: Filters on the pathway to mental health care: II. Sociodemographic factors. Psychological Med 25:1149-1160, 1995.

48. Kessler RC, Nelson CB, McGonagle KA, Edlund MJ, Frank RG, Leaf PJ: The epidemiology of co-occurring addictive and mental disorders: Implications for prevention and service utilization. Am J Orthopsychiatry 66(1):17-31, 1996.

49. Sussman LK, Robins LN, Earls F: Treatment-seeking for depression by Black and White Americans. Soc Sci Med 24:87-196, 1987.

50. Fellin P: Mental Health and Mental Illness. Itasca, IL, Peacock, 1996.

51. Wagenfeld MO, Jacobs JH: The community mental health movement: Its origins and growth, in Wagenfeld MO, Lemkau PV, Blair J (eds.): Public Mental Health: Perspectives and Prospects. Beverly Hills, CA, Sage, 1982.

52. Gurin G, Veroff J, Feld S: Americans View Their Mental Health. New York, Basic Books, 1960.

53. Star S: What the Public Thinks About Mental Health and Mental Illness. Paper presented to the National Association for Mental Health, Chicago, November 1952.

54. Star S: The Public's Ideas About Mental Illness. Paper presented to the National Association for Mental Health, Indianapolis, IN, November 1955.

55. Roof WC, McKinney W: American Mainline Religion: Its Changing Shape and Future. New Brunswick, NJ, Rutgers University Press, 1987. 
56. Larson DB, Sherrill KA, Lyons JS: Neglect and misuse of the $R$ word: Systematic reviews of religious measures in health, mental health, and aging, in Levin JS (ed.): Religion in Aging and Health: Theoretical Foundations and Methodological Frontiers. Thousand Oaks, CA, Sage, 1994, pp. 178-195. 